\title{
"Diffusion of COVID-19 impact across selected stock markets: a wavelet coherency analysis"
}

\begin{tabular}{|c|c|}
\hline & Taufeeque Ahmad Siddiqui (D https://orcid.org/0000-0002-3149-2234 \\
\hline AUTHORS & Haseen Ahmed (D https://orcid.org/0000-0002-8721-6132 \\
\hline & Mohammad Naushad (D https://orcid.org/0000-0003-4421-3422 \\
\hline ARTICLE INFO & $\begin{array}{l}\text { Taufeeque Ahmad Siddiqui, Haseen Ahmed and Mohammad Naushad (2020). } \\
\text { Diffusion of COVID-19 impact across selected stock markets: a wavelet } \\
\text { coherency analysis. Investment Management and Financial Innovations, 17(4), } \\
\text { 202-214. doi:10.21511/imfi.17(4).2020.19 }\end{array}$ \\
\hline DOI & http://dx.doi.org/10.21511/imfi.17(4).2020.19 \\
\hline RELEASED ON & Thursday, 03 December 2020 \\
\hline RECEIVED ON & Saturday, 29 August 2020 \\
\hline ACCEPTED ON & Friday, 20 November 2020 \\
\hline & $(\mathrm{ccc}) \mathrm{EY}$ \\
\hline LICENSE & $\begin{array}{l}\text { This work is licensed under a Creative Commons Attribution } 4.0 \text { International } \\
\text { License }\end{array}$ \\
\hline JOURNAL & "Investment Management and Financial Innovations" \\
\hline ISSN PRINT & $1810-4967$ \\
\hline ISSN ONLINE & $1812-9358$ \\
\hline PUBLISHER & LLC "Consulting Publishing Company "Business Perspectives" \\
\hline FOUNDER & LLC "Consulting Publishing Company "Business Perspectives" \\
\hline
\end{tabular}

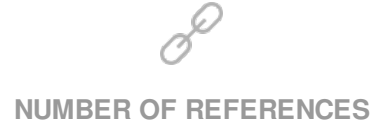

48

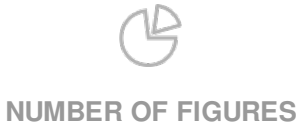

10
$-=-$
$-=-$

NUMBER OF TABLES

0

(C) The author(s) 2021. This publication is an open access article. 


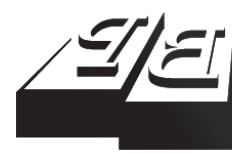

\section{BUSINESS PERSPECTIVES}

(O)

LLC "CPC "Business Perspectives"

Hryhorii Skovoroda lane, 10,

Sumy, 40022, Ukraine

www.businessperspectives.org
Received on: $29^{\text {th }}$ of August, 2020 Accepted on: $20^{\text {th }}$ of November, 2020 Published on: $3^{\text {rd }}$ of December, 2020

(C) Taufeeque Ahmad Siddiqui, Haseen Ahmed, Mohammad Naushad, 2020

Taufeeque Ahmad Siddiqui, Dr., Assistant Professor, Centre for Management Studies, Jamia Millia Islamia, New Delhi, India.

Haseen Ahmed, Research Scholar, Centre for Management Studies, Jamia Millia Islamia, New Delhi, India.

Mohammad Naushad, Dr., Assistant Professor, College of Business Administration- Alkharj, Prince Sattam Bin Abdulaziz University, Saudi Arabia. (Corresponding author)
This is an Open Access article, distributed under the terms of the Creative Commons Attribution 4.0 International license, which permits unrestricted re-use, distribution, and reproduction in any medium, provided the original work is properly cited.

Conflict of interest statement: Author(s) reported no conflict of interest
Taufeeque Ahmad Siddiqui (India), Haseen Ahmed (India), Mohammad Naushad (Saudi Arabia)

DIFFUSION OF COVID-19

IMPACT ACROSS SELECTED STOCK

MARKETS: A WAVELET COHERENCY ANALYSIS

\begin{abstract}
COVID-19 has impacted the world economy in an unprecedented manner; the financial markets indicate the same. This spontaneous event landed most of the stock markets into extreme volatility. Large capital outflow and extreme rapid fall were seen among almost all the world financial markets. Though similar trend prevailed everywhere during this pandemic, the impact could not be accumulated in absolute terms. Using the data of five stock markets, the current study endeavored to draw an impact of COVID-19 on major stock exchanges. The study uses wavelet coherency analysis on one-year daily data from June 2019 to May 2020 of five stock markets: Bombay Stock Exchange (BSE), London Stock Exchange (LSE), NASDAQ, Tokyo Stock Exchange (Nikkei), and Shanghai Stock Exchange. It is observed that there are time-variation and scale-variation in co-movements between the studied markets. During the crisis, the co-movement concentrates on a short time scale, even for two days. These results have significant implications for international investors, which will help them in portfolio diversification with time elements. All the stock markets under study have indicated co-movement at different time scales and frequencies with varying cross-power levels. However, the concentration of co-movement is found the most between the UK and the US stock markets. It is the least between Japan and the UK. In BSE, co-movement at shorter time scales started late. NASDAQ is leading only in one case, i.e., Shanghai Stock Exchange. BSE is not leading any stock index. LSE is in the leading position in all four cases. It has also been observed that co-movement started to concentrate at a shorter time scale as soon as the impact of the crisis increased.
\end{abstract}

\section{Keywords}

portfolio management, investment management, stock market, COVID-19, wavelet analysis, co-movement analysis

\section{JEL Classification $\quad$ E22, F32, G24, G32, O16}

\section{INTRODUCTION}

The impact of COVID-19 on stock markets has been the most destructive after the Global Financial Crisis of 2008. The global economy is expected to be in recession in 2020 due to medical emergencies and its response, particularly restrictions on movements (United Nations, 2020). The pandemic, which was a health emergency, rapidly led to an economic crisis. The crisis caused extreme volatility of the stock markets. During this time, world financial markets witnessed a rapid fall. Dow Jones registered the second-largest drop in its history, and Borsa Italiana (stock market of Italy) fell nearly by 17 percent. In late February 2020, several markets registered negative returns.

Bilateral trade and international investment opportunities increase the interdependence and integration of financial markets worldwide (Pretorius, 2002). Volatility in a stock market can impact the other markets (Loh, 2013), with a varying degree based on the level of integration between them. 
The past several studies have proved that the co-movement or integration between the stock markets further increases during the crisis. Park and Song (1998), Baig and Goldfajn (1998), and Jang and Sal (2001) studied the Asian financial crisis of 1997. Financial crisis due to COVID-19 finds resemblance with the stock market crash of 2008. Several studies investigated the co-movement during the Global Financial Crisis of 2008, such as Graham et al. (2013), Loh (2013), and Kiviaho et al. (2012). The mentioned studies have found evidence of increased interdependence between the markets during the crises.

The increased interdependence during the crises, in turn, enhances the risk for the investors. The phenomenon limits portfolio diversification opportunities in international financial markets (Dalkir, 2009; Naushad \& Malik, 2015). The same was also witnessed during the earlier crisis (Khan \& Park, 2009; Nikkinen et al., 2012). The apparent dynamic co-movement between the world stock markets during different crises is the motivation for this research.

During the crisis, it is common for investors to change their behavior and perception of investment in the financial markets. The investors are in a dilemma regarding the market and time of investment. This uncertainty is manifested by trends of financial markets and spillover effects. Wavelet coherency measures the co-movement in the time domain and in the frequency domain (Rau \& Nunes, 2009; Naushad, 2020), which is of benefit to investors. The analysis presents the results based on the time horizon and the investment frequency (Barunik, Vacha, \& Kristoufek, 2011). Thus, the present study analyzes the dynamic co-movement relationship between different stock markets in the background of the COVID-19 pandemic. The association is assessed in diverse time and frequency domain using wavelet coherency analysis.

\section{LITERATURE REVIEW}

The co-movement between the stock markets around the world has been studied extensively. This increased interdependency between the markets can be attributed to increased bilateral trade (Pretorius, 2002). There is vast literature available on the stock markets' co-movements. Moranna and Beltratti (2008) analyzed the co-movement relationship between the USA, the UK, Germany, and Japan using a common factor model on realized variance and correlations of mentioned stock markets. Leong and Felmingham (2003) applied Granger causality and multivariate cointegration to investigate the co-movement between the Asian stock markets' stock indexes, namely Nikkei, Hang Seng, Straits Times Index, Korea Composite Stock Price Index, and Taiwan Weighted. The results show the increased correlation between the studied stock markets. Similar interdependence between the stock markets has also been found to a varying degree in Brooks and Del Negro (2004) and Kizys and Pierdzioch (2009). Lee and Jeo (1995) find the common trend between the US and Japanese stock markets. Johnson and Soenen (2003) examined the stock market and level of integration of the Americas' markets by apply- ing Gweke's measure of linear dependence and finds that the markets of Argentina, Brazil, Chile, Mexico, and Canada are correlated with the US stock market. The impact of economic news on co-movement is investigated by Albuquerque and Vega (2009). This study applied a framework based on conditional correlations. Graham et al. (2012) examined the co-movement between Finnish and international stock markets. The findings show that co-movement is very strong for all the markets, whereas, with developed markets of Europe and America, co-movement is found at comparatively lower frequencies.

As markets are becoming more open to foreign investors, the integration of financial markets has also made them susceptible to the frequent global crisis. There is evidence of its increased interdependence during the crisis (Dalkir, 2009; Leong \& Felmingham, 2003). Baig and Goldfajn (1998) and Forbes and Rigobon (2002) find interdependence between the stock markets during the 1987 US market crash, the Asian financial crisis of 1997, and Mexican devaluation of 1994. Leong and Felmingham (2003) investigated the co-movement between the stock markets of Hong Kong, Taiwan, Japan, South Korea, and Singapore, and observed 
an increased correlation during the 1997 Asian crisis. Khan and Park (2009) have also analyzed cross-correlation between the stock markets during the Asian crisis of 1997.

Various studies find market co-movement during the US sub-prime crisis (Dooley \& Hutchinson, 2009; Hwang et al., 2011; Nkkinen et al., 2012). Dooley and Hutchinson (2009) analyzed the transmission of the US sub-prime crisis to emerging markets using different regression methods. The results show that Korea, China, and Malaysia have linkages during the later stages of the US subprime crisis. Nikkinen et al. (2012) found an interdependence between the Baltic stock markets (Estonia, Lithuania. and Latvia) and European stock markets during the US sub-prime crisis.

The earliest use of wavelet analysis in studying the relationship between economic and financial variables is found in the work of Ramsey and Zhang (1997) and Ramsey and Lampart (1998a, 1998b). Application of wavelet analysis is a recent trend in the analysis of economic and financial time series data. Well-known works, which have used wavelet coherency in studying co-movement across financial markets, are Rau and Nunes (2009), Aloui and Hkiri (2014), and Dankir (2004).

Lee (2004) applied discrete wavelet analysis to examine the stock market co-movement between the United States and South Korea and found the co-movement between the United States and South Korea. Rau and Nunes (2009) investigated the co-movement between stock markets of the UK, Germany, the USA, and Japan from 1973 to 2007. The study shows co-movement between the US and European markets, whereas Japan is independent of both the markets. There is increased interdependence between Germany, the UK, and the USA after 2000. Barunik, Vacha, and Kristoufek (2011) apply wavelet analysis to study contagion between Eastern and Central European markets during the financial crisis. The results showed the correlations between Central and Eastern European markets at different frequencies and time scales. Das (2018) analyzed the correlation and interdependence between developed and emerging markets after the Global Financial Crisis of 2008. Further, Loh (2013) investigated the co-movement between 13 AsiaPacific stock markets and the US and European stock markets using the wavelet coherence analysis. The result finds co-movement between the European and US stock markets and most of the Asia-Pacific markets.

Hence, the review of earlier studies reveals that vast literature is available on stock markets' co-movement. The co-movement or interdependence have been studied during various crises as well. By and large, techniques used in the studies are correlation, cointegration, various forms of regression, and different GARCH models. There is a dearth of studies on applying wavelet analysis on financial markets, particularly during the recent crisis. The present study applies wavelet coherency analysis on five stock markets to assess shock transmission due to COVID-19. In wavelet analysis, the relationship is examined in the time and frequency domain, unlike the mentioned methods, which ignore the relationship in the frequency domain (Power \& Turvey, 2010; Huang et al., 2016; Ramsey, 2002).

\section{AIMS OF THE STUDY}

The study's main purpose is to assess transmission of shock due to COVID-19 between five stock markets, namely, Bombay Stock Exchange (SENSEX), London Stock Exchange (FTSE100), New York Stock Exchange (NASDAQ), Tokyo Stock Exchange (Nikkei), and Shanghai Stock Exchange (Shanghai Composite). The relationship is examined in different time and frequency domain. Moreover, the study examines the dynamic co-movement between the stock markets.

\section{RESEARCH METHODOLOGY}

The study uses daily data of five stock markets from June 2019 to May 2020. These are BSE of India, Tokyo Stock Exchange, London Stock Exchange (LSE), Shanghai Stock Exchange of China, and the USA's NASDAQ (NASDAQ Composite (IXIC)). To avoid mismatches in the dates, necessary adjustments have been made.

The study applies the wavelet coherency method using the R-Studio software package on the mentioned stock markets to assess transmission of 
shock owing to COVID-19. Wavelet analysis finds its origin in signal processing (Ramsey, 2002). Recent applications of wavelet analysis have percolated in image processing, medicine, geophysics, astrophysics, etc. Various studies have used a wavelet to analyze financial and economic data (Loh, 2013; Rua \& Nunes, 2009; Kiviaho et al., 2012). In wavelet analysis, the relationship is examined in the time and frequency domain, unlike in commonly used methods, which ignore the relationship in the frequency domain (Power \& Turvey, 2010; Huang et al., 2016; Ramsey, 2009). Another advantage of wavelet analysis is that it is independent of the condition of stationarity, which can distort the findings in time series analysis (Gencay et al., 2002).

Wavelets are small waves originating from a mother wavelet, which grow and decay in a limited time. A mother wavelet can be written as follows:

$$
\psi_{\tau, s}(t)=\frac{1}{\sqrt{s}} \psi\left(\frac{t-\tau}{s}\right),
$$

where $\psi(t)$ is a complex wavelet function, and $1 / \sqrt{s}$ is normalization factor ensuring the unit variance of wavelet (Aloui \& Hkiri, 2014). Locational parameter, $\tau$, keeps the wavelet in the exact position, whereas $s$ determines the way wavelet is stretched and dilated. The present study uses Morlet wavelet, which is given by

$$
\psi(t)=\pi^{-\frac{1}{4}} e^{-i \omega_{0} t} e^{-t \frac{2}{2}}
$$

Morlet wavelet is a commonly used wavelet (Kiviaho et al., 2012; Rua \& Nunes, 2009), where $\omega$ represent the frequency, which is taken as 6 for balance between time and frequency scale (Grinsted et al., 2004), whereas $t$ denotes the dimensionless time parameter. Further, in wavelet analysis, wavelet coherence can be understood as a local correlation between the two time series in frequency and time scale (Torrence \& Webster, 1999). Torrence and Webster (1999) describe wavelet coherence as follows:

$$
R^{2}(u, s)=\frac{\left|s\left(s^{-1} w_{x y}(u, s)\right)\right|^{2}}{s\left(s^{-1}\left|w_{x}(u, s)\right|^{2}\right) s\left(s^{-1}\left|w_{y}(u, s)\right|^{2}\right)},
$$

where $s$ is smoothing factor (Rua \& Nunes, 2009), without smoothing factor coherency is 1 at all scales of frequency and time. The val- ue of coherency is 0 to 1 depending upon the strength of co-movement. It can be interpreted as the coefficient of correlation, which indicates that the higher the value, the higher the correlation, whereas a lower value means low coherency (Kiviaho et al., 2012). Graphical representation also shows the coherency, where the red area shows stronger co-movement between the time series, whereas the green color indicates no co-movement between the two series. The dark color area is considered a cone of significance at $5 \%$, while the area outside is of no significance (Torrence \& Compo, 1998; Percival \& Walden, 2000). Cross-wavelet, as defined by Hudgins et al. (1993) and Torrence and Compo (1998), is given as follows:

$$
\text { ùùìle },)={ }_{x}(,)_{y}(,),
$$

where $w_{x}$ and $w_{y}$ are transformed wavelets, $u$ is position, and $s$ is scale.

As used in Loh (2013), an arrow represents the phase. It can be interpreted as when series move together, there is zero phase difference between them. When they move in the right (left) direction, they are in phase and move together, whereas the left direction indicates that they are anti-phase and move in the opposite direction. Arrows in the upper direction indicate that the first-time series leads the second, while the down direction shows that the second-time series leads the first one.

\section{DATA AND DESCRIPTIVE STATISTICS}

Table 1 indicates that daily mean returns of NASDAQ, LSE, and Tokyo Stock Exchange (Nikkei) are positive, whereas BSE and Shanghai Stock Exchange show negative returns. Volatility is the least for NASDAQ as the standard deviation is 0.07 , whereas Shanghai Stock Exchange shows the highest standard deviation of 0.84 . Skewness is negative for all the markets, excluding NASDAQ. Kurtosis is more than 3 in the case of BSE, LSE, NASDAQ, and Tokyo Stock Exchange (Nikkei). It is the highest (3.49) for Tokyo Stock Exchange (Nikkei) and the lowest (2.74) for Shanghai Stock Exchange. 
Table 1. Descriptive statistics

\begin{tabular}{|c|c|c|c|c|c|}
\hline Particular & BSE & $\begin{array}{c}\text { Shanghai Stock } \\
\text { Exchange }\end{array}$ & NASDAQ (IXIC) & LSE & $\begin{array}{c}\text { Tokyo Stock } \\
\text { Exchange (N225) }\end{array}$ \\
\hline Mean & -0.0008676 & -0.000084 & 0.0007225 & 0.001680 & 0.0002343 \\
\hline Median & 0.0001819 & 0.0000503 & 0.0017869 & 0.001645 & 0.0008941 \\
\hline Max. & 0.0859474 & 0.003098 & 0.0893470 & 0.142701 & 0.0773138 \\
\hline Min & -0.141017 & -0.008039 & -0.1314916 & -0.101641 & -0.0627357 \\
\hline Stand. D & 0.112226 & 0.8484401 & 0.070490 & 0.110752 & 0.081145 \\
\hline Skewness & -1.198629 & -0.178142 & 0.006782 & -0.824340 & -0.806540 \\
\hline Kurtosis & 3.302843 & 2.748088 & 3.006007 & 3.046116 & 3.496370 \\
\hline
\end{tabular}

Table 2 describes a time scale on the horizontal axis and the corresponding time of data used in the wavelet coherency plot. Time scale 151-200 is of interest in the study, which corresponds to events such as suspension of international flights, strict lockdowns, and declaration of COVID-19 as a pandemic by the World Health Organisation (WHO).

Table 2. Time scale

\begin{tabular}{l|c}
\hline \multicolumn{1}{c|}{ Time scale } & Horizontal axis \\
\hline $1-50$ & June-Aug 2019 \\
\hline $51-100$ & Aug-Nov, 2019 \\
\hdashline $101-150$ & Nov 2019-Jan 2020 \\
$151-200$ & Jan-Mar 2020 \\
$201-250$ & April-May 2020 \\
\hline
\end{tabular}

\section{RESULTS}

Figure 1 depicts that warmer or red color area indicates significant interrelation between London Stock Exchange and Tokyo Stock Exchange (Nikkei). Cross-wavelet power signifying the level of correlation between the time series is the highest (0.7) with dark color areas, whereas blue color indicates no relationship between the variables under study. Strong co-movement is found for 8 and 16 time scales, which gradually decreases towards shorter time scales of 4 and 2. It is co-movement at a time scale of 2 , but weaker relative to the time scale of 8 and 16. Arrow's direction shows the phase between the variables. Thus, it can be inferred that London Stock Exchange is leading Tokyo Stock Exchange (Nikkei).

Figure 2 shows a strong co-movement between London Stock Exchange and NASDAQ from December to May (on a scale from 120 to the right end of the figure on the horizontal axis). Cross- wavelet power of 0.9 indicates strong co-movement between the London Stock Exchange and NASDAQ of the United States of America. There is strong co-movement at a scale of 8 and higher during the COVID-19 pandemic, which corresponds to the observation from 150 to 200 on the horizontal axis of the figure. Co-movement at the short time scale of 2 can also be observed. The direction of arrows is predominantly is right down, signifying London Stock Exchange is leading NASDAQ (NASDAQ Composite). Transmission of impact is not limited to London Stock Exchange but spread by it.

Figure 3 confirms that from January to March, co-movement between BSE of India and Shanghai Stock Exchange of China is found significant, given the cross-wavelet power of 0.7 during the COVID-19 pandemic. Strong co-movement is observed at a time scale of 16 and above, whereas at a time of scale 2, co-movement is relatively weaker. The phenomena were found only during the time corresponding to the COVID-19 pandemic. The direction of arrows is largely right up, indicating the dominancy of Shanghai Stock Exchange in leading the co-movement between Shanghai Stock Exchange and BSE. China being the first country to be impacted by the COVID-19, the impact of the crisis on its financial market was felt earlier.

Figure 4 shows the co-movement relationship between NASDAQ and Shanghai Stock Exchange. The relation is significant as the cross-wavelet power level is 0.6. There is shorter and weaker co-movement before COVID-19 than that of the post-COVID-19 scenario. Strong co-movement is observed at a short time scale of 2, which is observed during the peak of the crisis, whereas there is no co-movement at time scales of 4 and 8. Further strong co-movement is seen at higher 


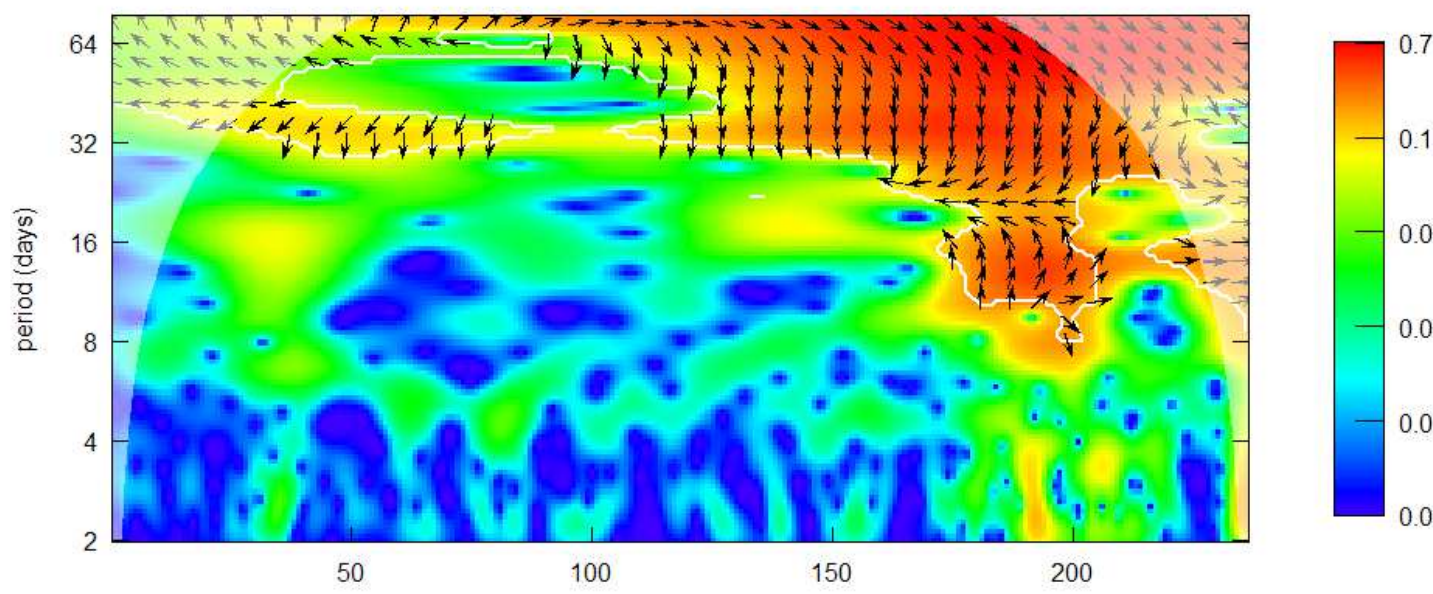

Figure 1. London Stock Exchange and Tokyo Stock Exchange (Nikkei)

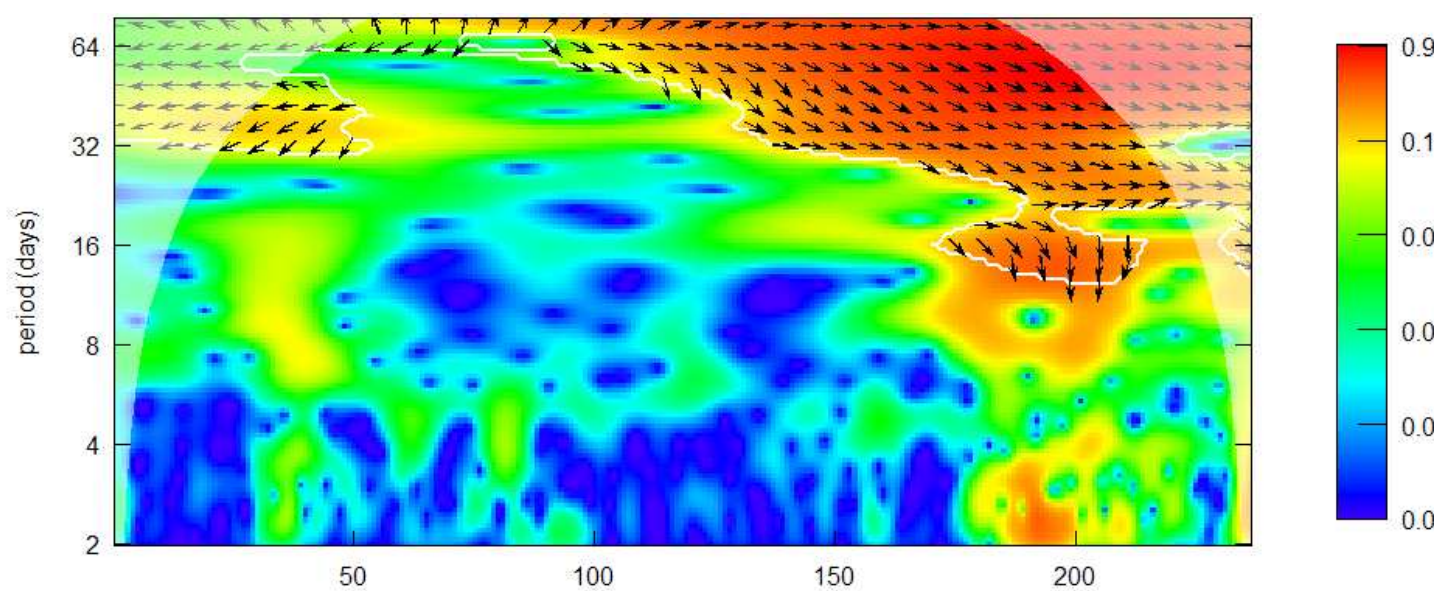

Figure 2. London Stock Exchange and NASDAQ
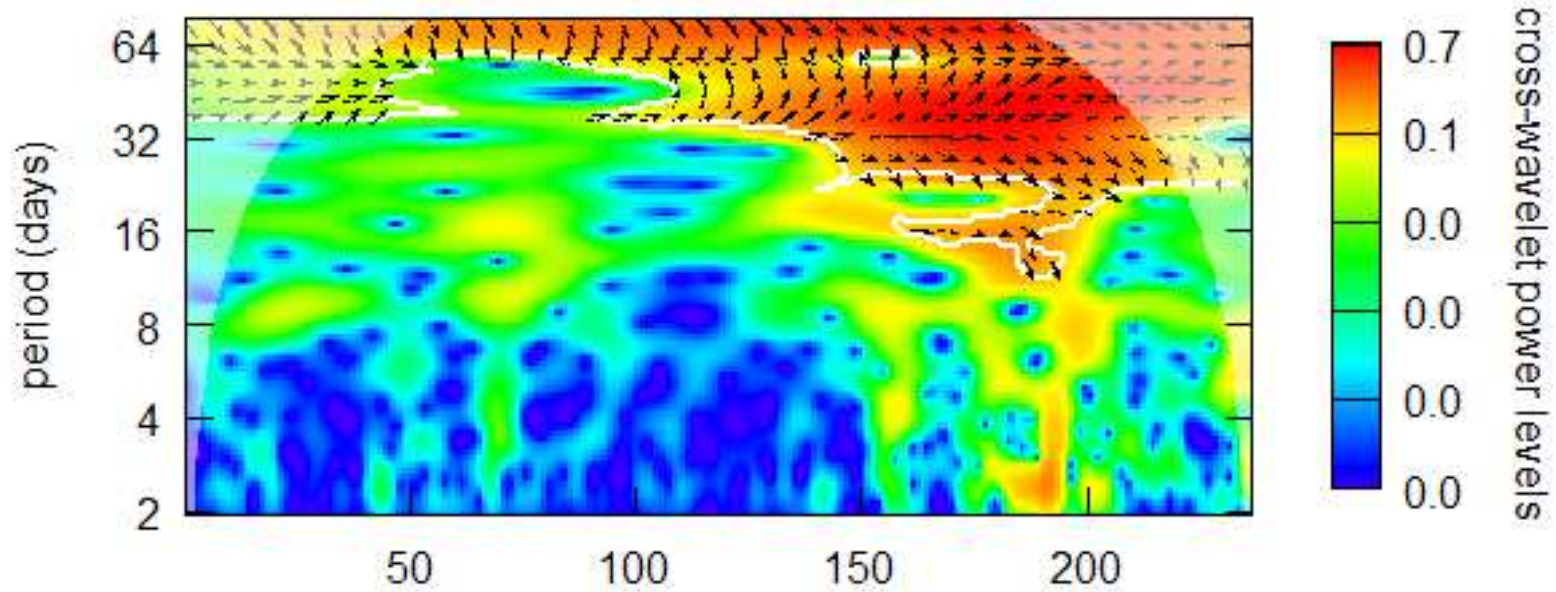

Figure 3. Shanghai Stock Exchange and BSE

scales of 16 and 32. Arrows are largely in the downward direction, which indicates that NASDAQ has a dominant leading position.

Figure 5 indicates the co-movement between NASDAQ and BSE. Significant co-movement at a short frequency of 2,4 , and 8 can be seen between the stock markets. Co-movement gradually became stronger at higher time scales. However, a leading and lagging relationship cannot be established as arrows' direction is dominantly in the right, i.e., anti-phase. 


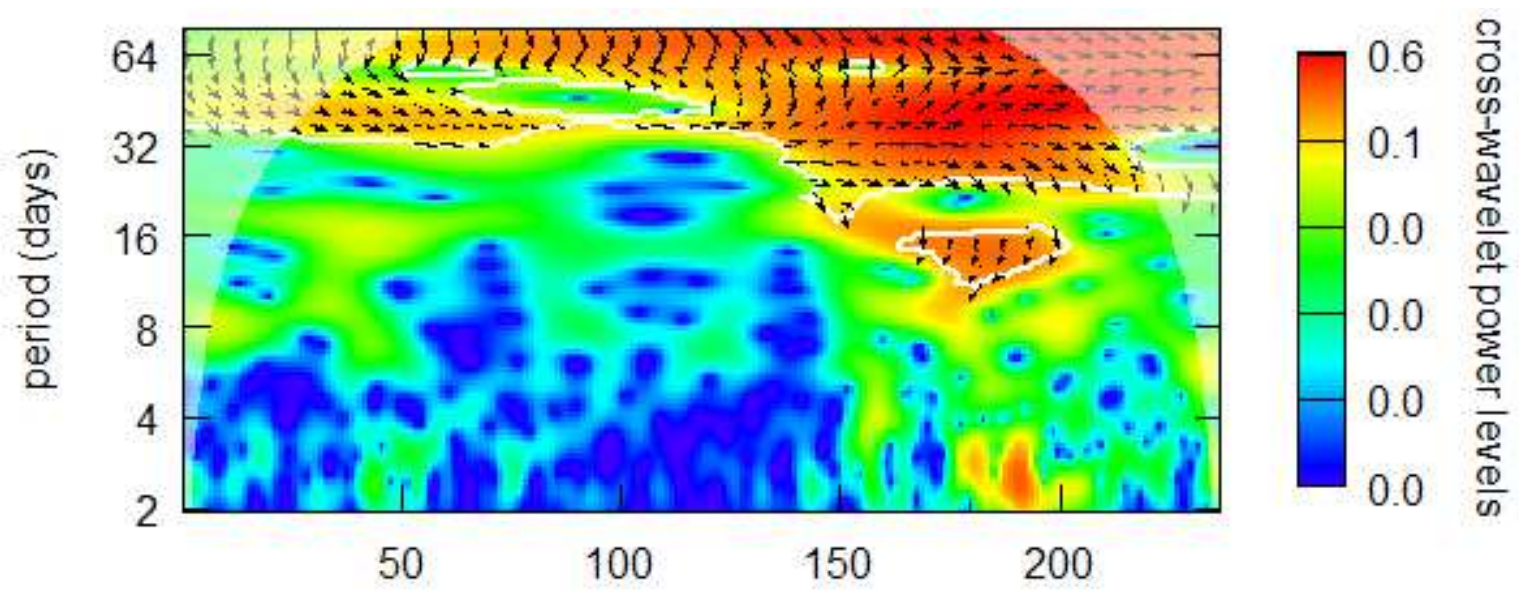

Figure 4. Shanghai Stock Exchange and NASDAQ

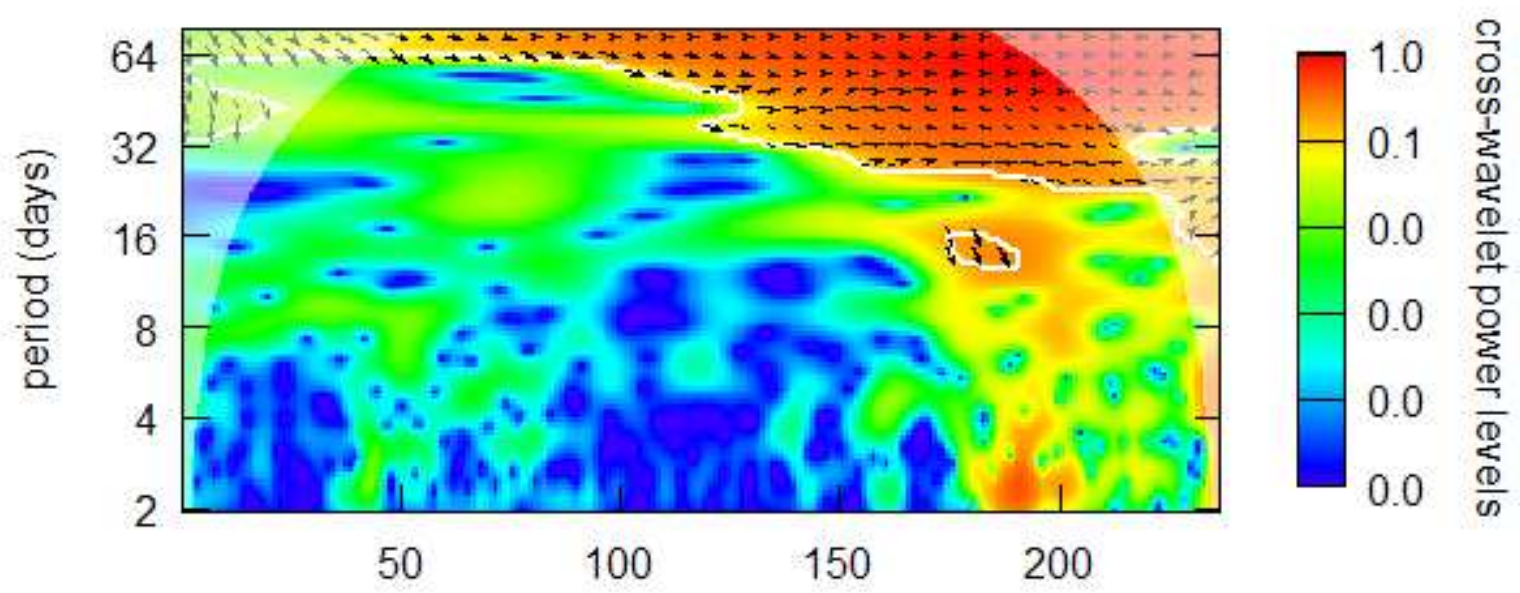

Figure 5. NASDAQ and BSE

Figure 6 demonstrates that there is a strong co-movement relationship between London Stock Exchange and BSE during the COVID-19 pandemic as per cross-wavelet power level. Most of the arrows are in the right direction, indicating that London Stock Exchange is leading BSE. Cross-wavelet power between the time series is 0.9 showing a significant relationship correlation between them. The dark red area in the figure is predominant during the COVID-19 pandemic. The red part of the coherency plot gradually increases as there is more transmission of virus across the countries. Strong co-movement can be seen at a shorter time scale of 16 days, which decreases further.

Figure 7 illustrates the wavelet-based coherency between Shanghai Stock Exchange and Tokyo Stock Exchange (Nikkei). It is significant as cross-wavelet power is 0.6 . The arrows' movement is relatively dominant in the right down direction, implying that Shanghai Stock Exchange is leading Tokyo Stock Exchange (Nikkei). There is co-movement between the markets before the COVID-19 pandemic, but it is weaker at a longer time scale than the COVID-19 pandemic. Co-movement at short time scales is weak and can be observed only for a time scale of 2, but increases at higher time scales of 16 and 32 .

Figure 8 shows that the correlation between Shanghai Stock Exchange and London Stock Exchange is significant, as indicated by the cross-wavelet power of 0.7. Co-movement, as shown in the dark area, is dominated in the period when the effect of COVID-19 started to emerge. The arrows' movement is largely in the right direction, indicating that London Stock Exchange is leading Shanghai Stock Exchange. The anti-phase direction is relatively much smaller as compared 
to the in-phase direction. Co-movement is largely dominated in 32 to 64 days frequency period. There is no co-movement at time scales of 8 and 16, though co-movement can be seen in a lower frequency of 2 .

Figure 9 exemplifies cross-wavelet power between Tokyo Stock Exchange (Nikkei) and NASDAQ (NASDAQ Composite) as 0.9 , which indicates a significant relationship between the data of Tokyo Stock Exchange (Nikkei) and NASDAQ. Comovement is strong at higher scales of 16 and 32 but cannot be observed for shorter time scales of 4 and 8 , apart from 2 . For 2 days, there is evidence of co-movement only during the time corresponding to the crisis. The direction of arrows is relatively dominant in the right direction, which indicates that NASDAQ is leading Tokyo Stock Exchange (Nikkei). The arrows' movement also shows Tokyo Stock Exchange (Nikkei) in the leading position at a larger scale, but gradually NASDAQ is shifting to the leading position.
As Figure 10 illustrates, the co-movement between Tokyo Stock Exchange (Nikkei) and BSE is significant from January to March. Co-movement is found even at a short-frequency level of 2 , which increases to higher level scales during the same period at a longer frequency scale of $4,8,16$, and so on. Strong co-movement largely corresponds with the crisis times. Arrows of left up to direction indicate that Tokyo Stock Exchange (Nikkei) is leading BSE.

Thus, it can be inferred that significant co-movement is found between BSE, LSE, NASDAQ, Tokyo Stock Exchange (Nikkei), and Shanghai Stock Exchange. The co-movement concentrates at longer time scales. The result is similar to the finding of Graham et al. (2012). all the stock markets have shown co-movement at different time scales and frequencies with varying levels of cross-power. The co-movement started to concentrate at a shorter time scale as the impact of the crisis due to COVID-19 augmented. It is similar

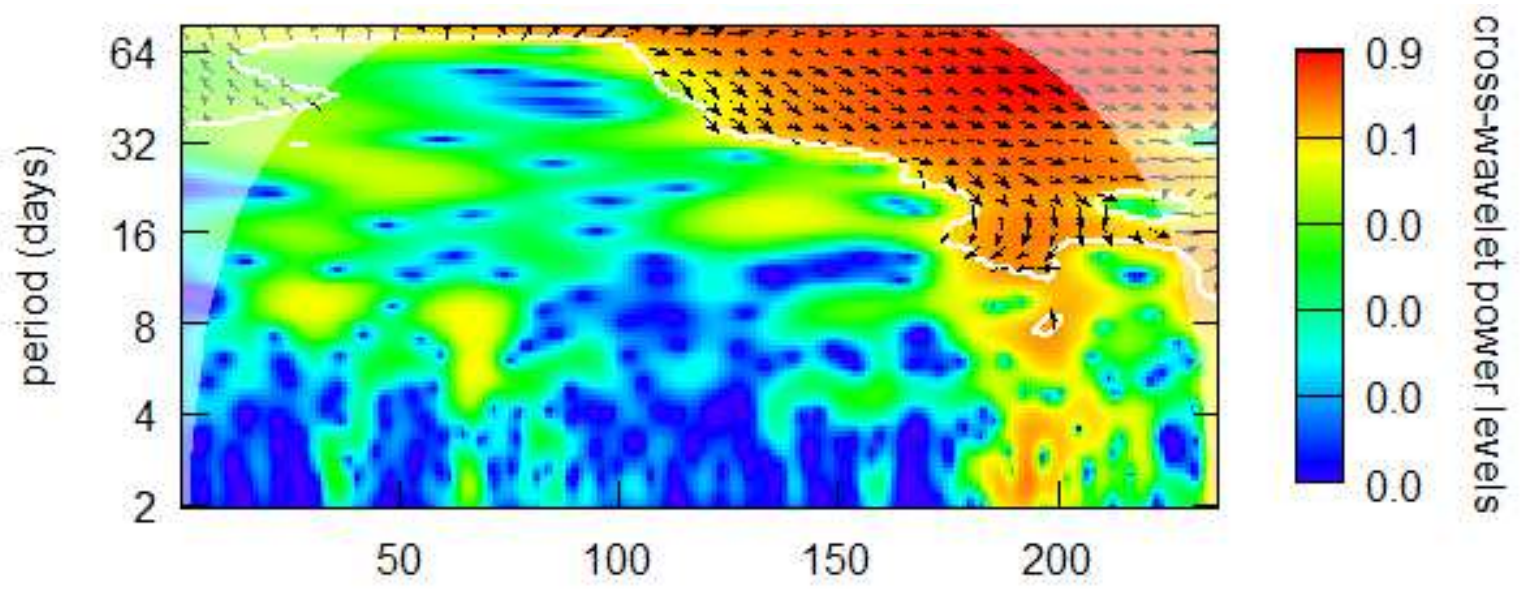

Figure 6. London Stock Exchange and BSE

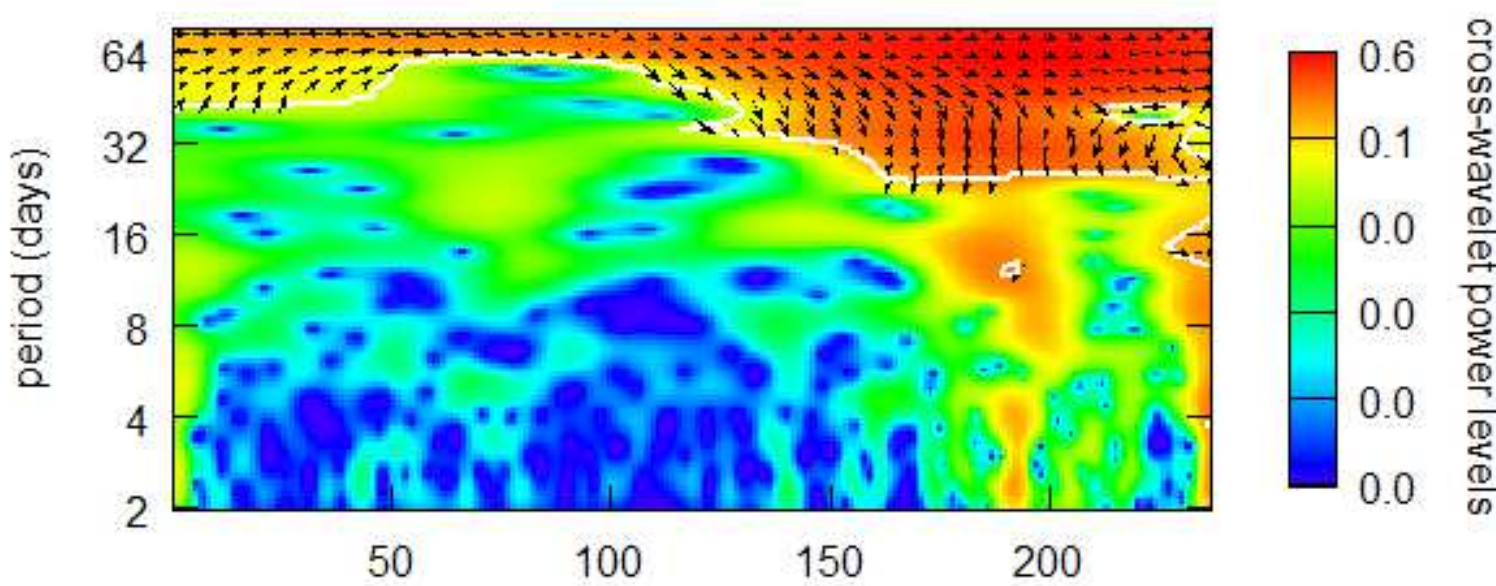

Figure 7. Shanghai Stock Exchange and Tokyo Stock Exchange (Nikkei) 


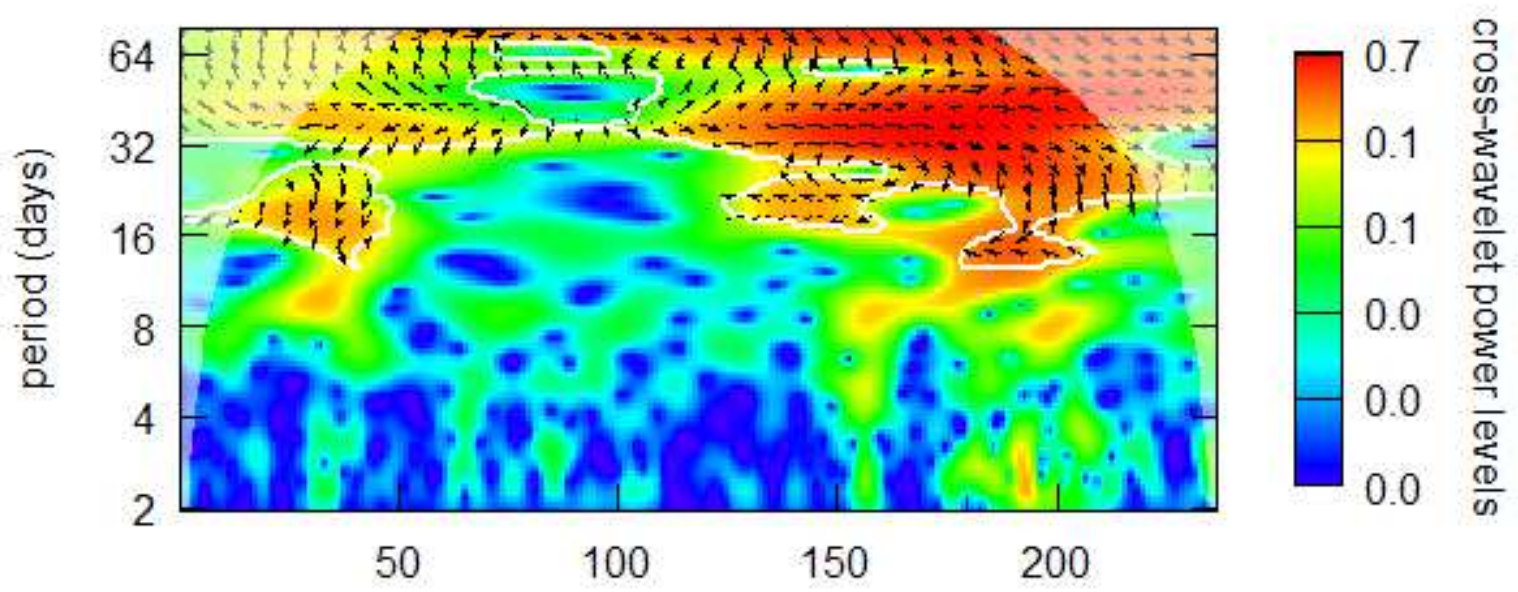

Figure 8. Shanghai Stock Exchange and London Stock Exchange
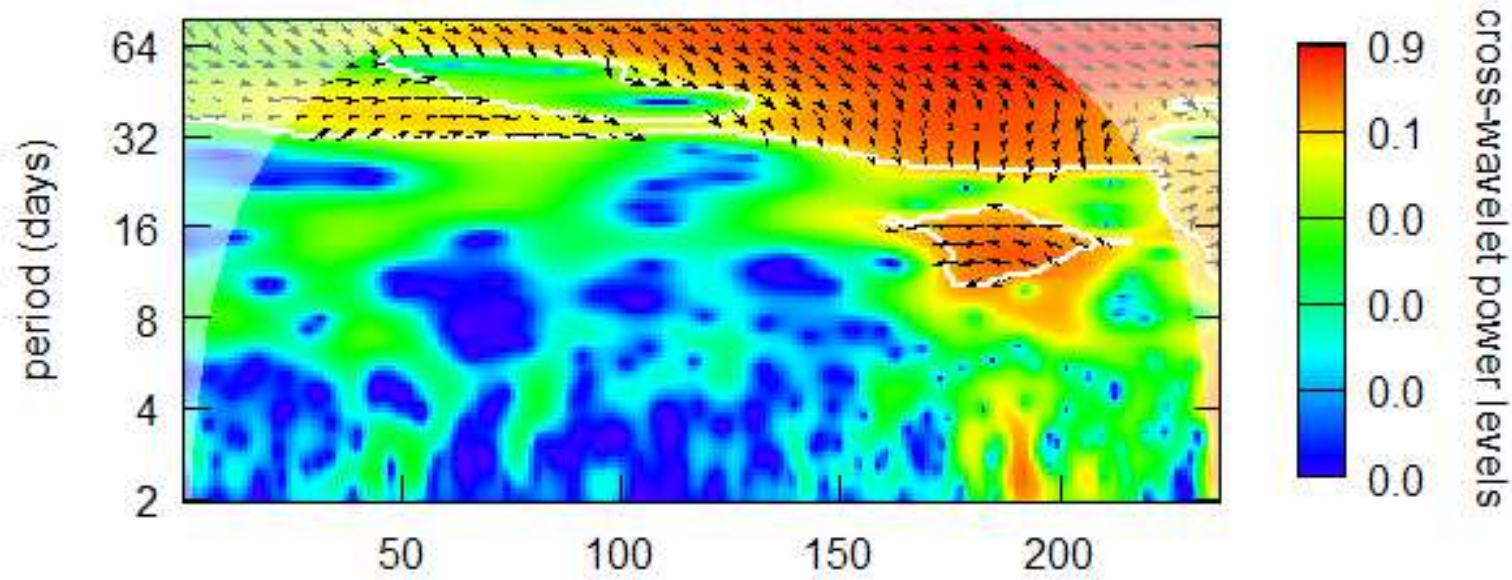

Figure 9. NASDAQ and Tokyo Stock Exchange (Nikkei)

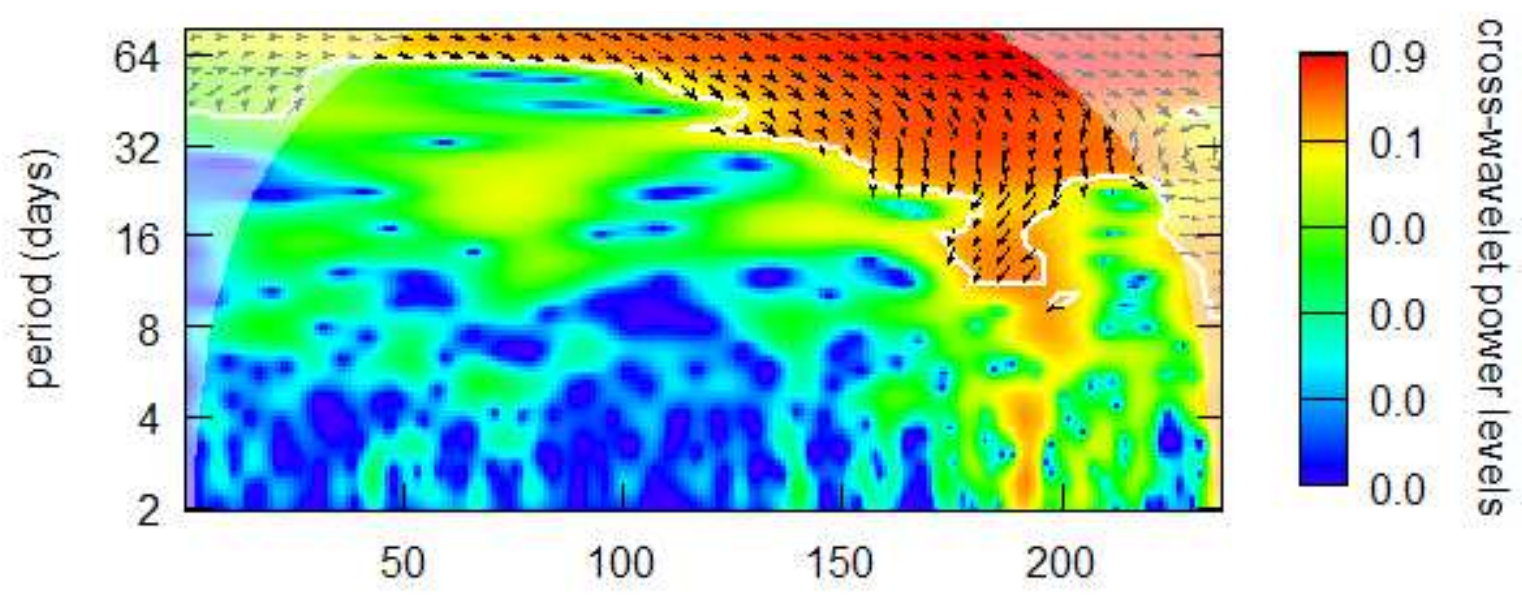

Figure 10. Tokyo Stock Exchange (Nikkei) and BSE

to the finding of Loh (2013), which indicates that during the crisis, co-movement is found at shorter time scales. Co-movement at the scale of 16 is observed from January to April. It is observed at shorter time scales of 2 and 4 days during the lat- ter half of March. The concentration of co-movement is found the most between stock markets of the UK and the USA. It is the least between Japan and the UK. In BSE, co-movement at shorter time scales started late. 
Out of four cases, NASDAQ is leading only in one case, i.e., Shanghai Stock Exchange. BSE is not leading any stock market. LSE is in the leading position in all four cases. Tokyo Stock
Exchange (Nikkei) is leading only in the case of BSE. Shanghai Stock Exchange is leading two stock markets: Tokyo Stock Exchange (Nikkei) and BSE.

\section{CONCLUSION AND IMPLICATIONS}

Though the impact of COVID-19 was initially seen in December 2020 initially, its large-scale impact was seen during the lockdown in Wuhan, a major industrial province of China. Impact gradually got worse when international flights were suspended in many countries, and reached its peak when WHO declared the COVID-19 as a global pandemic. In the background of these events, this study applied wavelet coherency analysis and found significant co-movement between the five stock markets (BSE, LSE, NASDAQ, Tokyo Stock Exchange (Nikkei), and Shanghai Stock Exchange). Co-movement is largely found during January and March 2020. The co-movement started to concentrate at a shorter time scale as the impact of the crisis enlarged. It was seen even at a short scale of 2 days. Co-movement is more persistent between NASDAQ and BSE, LSE and BSE, and Tokyo Stock Exchange (Nikkei) and BSE. It can be inferred that the BSE of India is relatively more integrated with these markets as compared to other markets under study. BSE did not lead any market, while LSE is in the leading position in all four cases. The findings of previous studies show that global financial markets are integrated (Pretorius, 2002). The results confirm the findings of the studies, such as Dalkir (2009) and Leong and Felmingham (2000), which find that markets are more correlated during the crisis. The results can be vital for international investors as an international investor attempts simultaneously to get the benefits of portfolio diversification and time diversification.

The results can be of interest to investors investing in different time horizons. Market co-movement is a vital determinant of portfolio diversification. The study shows that there are time-variation and scale-variation in co-movements between the studied markets. During the crisis, the co-movement concentrates at the short-time scale, even for two days. These results have significant implications for international investors as they attempt to get the benefits of time diversification in addition to portfolio diversification.

The present study attempts to assess the transmission of shock due to COVID-19 among five stock markets. For appraising the impact, wavelet analysis has been employed. Future researchers can consider other markets. A larger number of markets may also be used. Other advanced techniques like wavelet GARCH can be used to analyze the results in depth for analyzing the data.

\section{AUTHOR CONTRIBUTIONS}

Conceptualization: Mohammad Naushad, Taufeeque Ahmed Siddiqui.

Data curation: Taufeeque Ahmed Siddiqui.

Formal analysis: Haseen Ahmed.

Investigation: Mohammad Naushad.

Methodology: Taufeeque Ahmed Siddiqui.

Project administration: Taufeeque Ahmed Siddiqui.

Resources: Mohammad Naushad.

Supervision: Mohammad Naushad, Taufeeque Ahmed Siddiqui.

Validation: Haseen Ahmed.

Visualization: Haseen Ahmed.

Writing - original draft: Haseen Ahmed.

Writing - review and editing: Mohammad Naushad. 


\section{REFERENCES}

1. Albuquerque, R., \& Vega, C. (2009). Economic News and International Stock Market Comovement. Review of Finance, 13(3), 401-465. https://doi. org/10.1093/rof/rfn020

2. Aloui, C., \& Hkiri, B. (2014). Comovements of GCC emerging stock markets: New evidence from wavelet coherence analysis. Economic Modelling, 36, 421-431. https://doi.org/10.1016/j.econmod.2013.09.043

3. Baig, T., \& Goldfajn, I. (1998). Financial Market Contagion in the Asian Crisis (IMF working paper, 98-155). Retrieved from https:// www.imf.org/en/Publications/ WP/Issues/2016/12/30/FinancialMarket-Contagion-in-the-AsianCrisis-2791

4. Barunik, J., Vacha, L., \& Kristoufek, L. (2011). Comovement of Central European Stock Markets using wavelet coherence: Evidence from high frequency data (IES Working Paper). Retrieved from https://www.econstor.eu/handle/10419/83377

5. Brooks, R., \& Del Negro, M. (2004). The rise in co-movement across national stock markets: market integration or IT bubble? Journal of Empirical Finance, 11(5), 659-680. https://doi.org/10.1016/j. jempfin.2003.08.001

6. Brooks, R., \& Del Negro, M. (2005). Country versus region effects in international stock returns. Journal of Portfolio Management, 31(4), 67-72. https:// doi.org/10.3905/jpm.2005.570152

7. Dalkir, M. (2004). A new approach to causality in the frequency domain. Economics Bulletin, 3(44), 1-14. Retrieved from https://www.researchgate. net/publication/4827395_A_new_ approach_to_causality_in_the_ frequency_domain

8. Dalkir, M. (2009). Revisiting Stock Market Index Correlations. Finance Research Letters, 6(1), 23-33. https://doi.org/10.1016/j. frl.2008.11.004
9. Das, D., Kannadhasan, M., Tiwari, A. K., \& Al-Yahyaee, K. H. (2018). Has co-movement dynamics in emerging stock markets changed after global financial crisis? New evidence from wavelet analysis. Applied Economics Letters, 25(20), 1447-1453. https://doi.org/10.1080 /13504851.2018.1430307

10. Dooley, M., \& Hutchinson, M. (2009). Transmission of the US subprime crisis to emerging markets: evidence on the decoupling-recoupling hypothesis. Journal of International Money and Finance, 28, 1331-1349. Retrieved from https://www.nber.org/papers/w15120

11. Felmingham, D., \& Grüneberg, R. N. (2000). The Alexander Project 1996-1997: latest susceptibility data from this international study of bacterial pathogens from community-acquired lower respiratory tract infections. Journal of Antimicrobial Chemotherapy, 45(2), 191-203. Retrieved from https://pubmed. ncbi.nlm.nih.gov/10660501/

12. Forbes, K., \& Rigobon, R. (2002). No contagion, only interdependence: measuring stock market co-movements. Journal of Finance, 57, 2223-2261. https://doi. org/10.1111/0022-1082.00494

13. Gencay, R., Selcuk, F., \& Whitcher, B. (2002). An Introduction to Wavelets and Other Filtering Methods in Finance and Economics. Academic Press, San Diego, CA. Retrieved from https://www.amazon.com/Introduction-WaveletsFiltering-Methods-Economics/ dp/0122796705

14. Graham, M., Kiviaho, J., \& Nikkinen, J. (2012). Integration of 22 emerging stock markets: a threedimensional analysis. Global Finance Journal, 23, 34-47. https:// doi.org/10.1016/j.gf.2012.01.003

15. Graham, M., Kiviaho, J., \& Nikkinen, J. (2013). Global and regional co-movement of the MENA stock markets. Journal of Economics and Business, 65, 86-100. https://doi.org/10.1016/j. jeconbus.2012.09.005
16. Grinsted, A., Moore, J. C., \& Jevrejeva, S. (2004). Application of the cross wavelet transform and wavelet coherence to geophysical time series. Nonlinear Processes in Geophysics, 11, 561-566. Retrieved from https://npg.copernicus.org/ articles/11/561/2004/

17. Hahn, L. S. (2004). International transmission of stock market movements: a wavelet analysis. Applied Economics Letters, 11(3), 197-201. Retrieved from https:// ideas.repec.org/a/taf/apeclt/v11y2004i3p197-201.html

18. Huang, S., An, H., Gao, X., \& Huang, X. (2016). Timefrequency featured co-movement between the stock and prices of crude oil and gold. Phys. Stat. Mech. Appl. 444, 985995. Retrieved from https:// www.researchgate.net/publication/284078239_Time-frequency_featured_co-movement_between_the_stock_and_prices_of_ crude_oil_and_gold

19. Hudgins, L., Friehe, A. C., \& Mayer, E. M. (1993). Wavelet Transform Atmospheric Turbulence. Physical Review Letters, 71(20), 3279. https://doi. org/10.1016/B978-0-08-0520841.50029-6

20. Hwang, I., In, F., \& Kim, T. S. (2011). Contagion and Spillover effects of US Subprime crisis: Evidence from international stock markets. Financial Contagion: The viral threat to wealth of the nations. John Wiley and Sons. https://doi. org/10.1002/9781118267646.ch28

21. Jang, H., \& Sul, W. (2002). The Asian financial crisis and the comovement of Asian stock markets. Journal of Asian Economics, 13(1), 94-104. Retrieved from https:// www.researchgate.net/publication/4878330_The_Asian_financial_crisis_and_the_co-movement_of_Asian_stock_markets

22. Johnson, R., \& Soenen, L. (2003). Economic integration and stock market co-movement in Americas. Journal of Multinational Financial Management, 13(1), 85-100. 
23. Khan, S., \& Park, K. (2009). Contagion in the stock markets: The Asian financial crisis revisited. Journal of Asian Economics, 20(5), 561569. https://doi.org/10.1016/j. asieco.2009.07.001

24. Kiviaho, J., Nikkinen, J., Piljak, V., \& Rothovius, T. (2012). The Co-movement Dynamics of European Frontier Stock Markets. European Financial Management, 20(3), 574-595. https://doi.org/10.1111/j.1468036X.2012.00646.X

25. Kizys, R., \& Pierdzioch, C. (2009). Changes in the international co-movement of stock returns and asymmetric macroeconomic shocks. Journal of International Financial Markets, Institutions and Money, 19(2), 289-305. https://doi.org/10.1016/j.intfin.2008.01.002

26. Lee, B.-S., \& Jeon, B. N. (1995). Common Stochastic Trends and Predictability of International Stock Prices. Journal of the Japanese and International Economies, 9(3), 245-277. Retrieved from https://ideas. repec.org/a/eee/jiieco/v9y1995i3p245-277.html

27. Lee, S. H. (2004). International transmission of stock markets movements: a wavelet analysis. Applied Economic Letters, 11, 197 201. Retrieved from http://www. mafhoum.com/press3/88E11.pdf

28. Leong, S., \& Felmingham, B. (2003). The interdependence of share markets in the developed economies of East Asia. PacificBasin Finance Journal, 11, 219237. https://doi.org/10.1016/ S0927-538X(03)00002-7

29. Loh, L. (2013). Co-movement of Asia-Pacific with European and US stock market returns: A cross-time-frequency analysis. Research in International Business and Finance, 29, 1-13. https://doi. org/10.1016/j.ribaf.2013.01.001

30. Morana, C., \& Beltratti, A. (2008). Co-movements in international stock markets. Journal of International Financial Markets, Institutions and Money, 18(1), 31-45. https://doi.org/10.1016/j. intfin.2006.05.001
31. Naushad, M. (2020). Investigating the technical and scale efficiency of cement companies in Saudi Arabia. Management Science Letters, 11(2), 339-346. Retrieved from https://www.researchgate. net/publication/344401691_Investigating_the_technical_and_ scale_efficiency_of_cement_companies_in_Saudi_Arabia

32. Naushad, M., \& Malik, S. A. (2015). Corporate governance and bank performance: A study of selected banks in GCC region. Asian Social Science, 11(9), 226. https://doi.org/10.5539/ass. v11n9p226

33. Nikkinen, J., Piljak, V., \& Äijö, J. (2012). Baltic stock markets and the financial crisis of 2008-2009. Research in International Business and Finance, 26(3), 398-409. https://doi.org/10.1016/j. ribaf.2012.03.003

34. Nikkinen, J., Pynnönen, S., Ranta, M., \& Vähämaa, S. (2010). Cross-dynamics of exchange rate expectations: a wavelet analysis. International Journal of Finance \& Economics, 167(3), 205-221. Retrieved from https://www.researchgate.net/ publication/228291165_CrossDynamics_of_Exchange_Rate_ Expectations_A_Wavelet_Analysis

35. Park, Y. C., \& Song, C. Y. (2001). Financial Contagion in the East Asian Crisis: With Special Reference to the Republic of Korea. International Financial Contagion. Springer, Boston, MA. Retrieved from https://www.researchgate. net/publication/239839029_Financial_Contagion_in_the_ East_Asian_Crisis_-_With_Special_Reference_to_the_Republic_of_Korea

36. Park, Y. C., \& Song, C. Y. (1999). The East Asian Financial Crisis: A Year Later. IDS Bulletin, 30(1), 93-107. Retrieved from https://opendocs.ids. ac.uk/opendocs/bitstream/ handle/20.500.12413/9133/ IDSB 30_1_10.1111j.1759-5436.1999.mp30001009.x .pdf;jsessionid $=2 \mathrm{~F} 83 \mathrm{BF} 8 \mathrm{D} 930 \mathrm{D}$ 5A5B676D9F4AFD8FF064?sequ ence $=1$
37. Percival, D. B., \& Walden, A. T. (2000). Wavelet Methods for Time Series Analysis. Cambridge University Press. https://doi. org/10.1017/CBO9780511841040

38. Power, G. J., \& Turvey, C. G. (2010). Long-range dependence in the volatility of commodity Futures prices: wavelet-based evidence. Phys. Stat. Mech. Appl., 389(1), 79-90. Retrieved from https://www.researchgate.net/ publication/222158246_Longrange_dependence_in_the_volatility_of_commodity_futures_prices_ Wavelet-based_evidence

39. Pretorius, E. (2002). Economic determinants of emerging stock market interdependence. Emerging Markets Review, 3(1), 84-105. https://doi.org/10.1016/ S1566-0141(01)00032-2

40. Ramsey, J., \& Lampart, C. (1998a). Decomposition of economic relationships by time scale using wavelets. Macro-economic Dynamics, 2(1), 49-71. Retrieved from https://www.cambridge.org/ core/journals/macroeconomicdynamics/article/abs/decomposition-of-economic-relationshipsby-timescale-using-wavelets $/ 510$ 3A9AAEE780CCA5EAAFEC29A DC8375

41. Ramsey, J., \& Lampart, C. (1998b). The decomposition of economic relationships by time scale using wavelets: Expenditure and income. Studies in Nonlinear Dynamics and Econometrics, 3(1), 23-42. https:// doi.org/10.2202/1558-3708.1039

42. Ramsey, J., \& Zhang, Z. (1997). The analysis of foreign exchange data using waveform dictionaries. Journal of Empirical Finance, 4, 341-372. https://doi.org/10.1016/ S0927-5398(96)00013-8

43. Ramsey, J. B. (2002). Wavelets in economics and finance: past and future. Stud. Non-Linear Dynam. Econom, 6(3), 1-29. Retrieved from http://plaza.ufl.edu/yiz21cn/ refer/wavelet\%20in\%20economics\%20and\%20finance.pdf

44. Rua, A., \& Nunes, L. C. (2009). International co-movement of stock market returns: A wavelet analysis. Journal of Empirical Finance, 16(4), 632-639. https:// 
doi.org/10.1016/j.jempfin.2009.02.002

45. Torrence, C., \& Webster, P. J. (1999). Interdecadal changes in the ENSO-monsoon system. Journal of Climate, 12(8), 2679-2690. https:// doi.org/10.1175/15200442(1999)012\%3C2679:ICITEM \%3E2.0.CO;2
46. Torrence, C., \& Compo, G. (1998). A practical guide to wavelet analysis. Bulletin of the American Meteorological Society, 79(1), 6178. https://doi.org/10.1175/15200477(1998)079\%3C0061:APGTW A\%3E2.0.CO;2

47. United Nations. (2020). UN/DESA Policy Brief \#59: Corona crisis causes turmoil in financial markets.
Retrieved from https://www. un.org/development/desa/dpad/ publication/un-desa-policy-brief59-corona-crisis-causes-turmoilin-financial-markets/

48. Vacha, L., \& Barunik, J. (2012). Co-movement of energy commodities revised: Evidence from wavelet coherence analysis. Energy Economics, 34(1), 241-247. https://doi.org/10.1016/j.eneco.2011.10.007 